\title{
Proceeding
}

8th INSHS International Christmas Sport Scientific Conference, 5-7 December 2013. International Network of Sport and Health

Science. Szombathely, Hungary

\section{Specifics of teaching physical education with focus on burden on PE teachers}

\author{
ZUZANA TULISOVÁ \\ ${ }^{1}$ Department of Social Sciences and Sport Management, Masaryk University Brno, Faculty of Sport Studies, Czech \\ Republic.
}

\begin{abstract}
Tulisová, Z. (2014). Specifics of teaching physical education with focus on burden on PE teachers. J. Hum. Sport Exerc., 9(Proc1), pp.S348-S354. The research, which this post is based on, is focused on examining of the specific of the physical education teachers. The aim of this paper is to present partial results of quantitative research focused on factors complaining the physical education teachers' work of. The factors were examined in several areas - occupational health conditions, physical stress, psychological stress, and the school team. The questionnaire was assembled on the basis of the search by Voltmann-Hummes (2008), who examined the burden of PE teachers and their ability to overcome it. The basis of database of PE teachers was the list of basic schools in the Czech Republic. From each region, casually 15 schools were chosen; it means 210 schools in total. The research was attended by 136 teachers, thereof 72 women and 64 men. Ages ranged between 24 and 66 years, the system ensured anonymity. Based on the evaluation of data, it was found out that the greatest burden for a teacher of physical education is pupils themselves, specifically their lack of motivation to do some exercises. The problem was the reluctance of students to move and non-practicing pupils who disrupt the course of a lesson. These results confirm other authors (e.g., Wong \& Louie, 2002, Woods, 2008). Other stressful factors were found to be less important and are a bit average rating. The data were compared to the data of the author of the original questionnaire, interpreted and discussed with regard to the realities in Czech schools. The obtained data were also compared with the results of the research authors who dealt with the stress in various areas as Kemeny (1998), König (2004), Rohnstock (2000) and the others. Key words: PE TEACHER, BURDEN, APPROACH OF TEACHING, PHYSIC STRESS, PSYCHOLOGICAL STRESS.
\end{abstract}

Corresponding author. Department of Social Sciences and Sport Management, Masaryk University Brno, Faculty of Sport Studies, Czech Republic.

E-mail: z.tulisova@gmail.com

8th INSHS International Christmas Sport Scientific Conference, 5-7 December 2013. International Network of Sport and Health Science. Szombathely, Hungary.

JOURNAL OF HUMAN SPORT \& EXERCISE ISSN 1988-5202

(c) Faculty of Education. University of Alicante

doi:10.14198/jhse.2014.9.Proc1.19

VOLUME 9 | Proc1 | 2014 | S348 


\section{INTRODUCTION}

The teaching profession attracts number of experts (eg, Berliner, 1993; Lukas, 2007, Průcha, 2002, Šimoník, 1994), and it even seems that teaching is one of the most common topics of educational researches. Already considerably less research attention is paid to physical education teachers, whose work in school is undoubtedly special (Blahutková et al., 2005), especially in relation to physical activities, the school climate or health school and all its stakeholders. Teaching physical education includes a number of specific projects and activities, eg. frequent trips outside school, pupils' motivation to physical activities, different concept of teaching, etc. Many authors even write about the obstacles restricting their fundamental mission - teaching and educating of students (Green, 1998, Wong \& Louie, 2002).

Concerning this, the article described particular burdening and aggravating factors of PE teachers' work, which we studied in several areas. Occupational health conditions, physical stress, psychological stress, and the school team.

\section{METHODS AND RESULTS}

The specifics of physical education teachers

For a description of the characteristics and specificities of teaching physical education, we chose a combination of quantitative and qualitative research. In the first phase of the research, the questionnaire was used, which was inspired by research Voltmann-Hummes (2008), who examined the burden of physical education teachers and their ability to cope with it. This research compares the burden on the teachers of different types of schools - elementary, grammar school, vocational school, etc. We focused only on secondary schools, because of the framework form of teaching content (as RVP) and differentiation of teachers at secondary schools according to the subjects taught.

Our questionnaire consisted of four parts, which were aimed at self-physical education teachers, teaching approaches, and load support. Total number of items in the questionnaire was 105. For the purposes of this post, only those items that relate to the issues discussed burdens physical education teacher in physical education classes in primary schools were selected from the questionnaire and processing.

The respondents were teachers of physical education of the second degree in Czech primary schools. The basis for the research group was a list of primary schools in the Czech Republic available on the website of the Ministry of Education, Youth and Sports (www.msmt.cz), which was selected randomly using the Microsoft Office (http://office.microsoft. com/cs-cz/excel-help/nahcislo-HP005209229.aspx). It was worked with 15 schools from each region, 210 schools in total. The management of these schools were sent a link to a website with a request PE teacher to fill in a questionnaire. We therefore accurate capture of how many PE teachers in this way we actually talked to. Sampling was not limited by the experience in the profession or by the size of the school.

The total number of completed questionnaires completely settled at number 136.

Characteristics of the research group

In terms of gender, the group of 72 women and 64 men, which clearly indicates a different gender distribution among physical education teachers and teachers of other subjects than describes Jüva (Lazarová, 2011). We do not take into account potential increased willingness of men to participate in surveys, which, as we know, has not been proven yet. 
The age of respondents ranged from 24 to 66 years, with an average age of 42.6 years. The highest number of respondents aged 31-40 (29\%); the dominant age is 33 years (8 persons). Similarly, research Voltmann-Hummes confirms the high frequency of teachers in the file aged $31-40$ years $(25.6 \%)$. From this perspective, our files are comparable.

The highest number of respondents - teaches at schools less than 5 years and the average length of experience in the investigation file is 17.3 years. It is obvious that the results obtained may be influenced by the relatively high number of respondents with minimal practice. On the other hand, it can be assumed that even after less than 5 years of practice, respondents are able to identify risks of their work.

In terms of subject combinations, only 11 teachers who were asked, taught physical education as the only subject, $92 \%$ of teachers teach also second or third subject. Mostly it is geography, followed mainly by science subjects such as mathematics, IT education, or biology.

\section{Stressors of physical education teachers}

On the professional burden in the questionnaire, we asked about eighteen items. Items were divided into the above-mentioned groups representing the burden physical education teacher. For all items, we used a Likert scale. It means that the number 1 corresponds to the statement "not burdensome" and the number 6 represents "very burdensome ". Respondents could answer "I cannot judge it" by the number 0.

Based on the evaluation of the data, we found that the burden of physical education teachers is not significant and the results are closer to the average rating. (Load Index - overall average of all items focused on the evaluation of load $=2.8$ ). As the most stressful factor consider physical education teachers low motivation of students to engage in physical education classes (3.61) and noise (3.45) and administration (3.43) the most stressful. See the table 1.

Table 1. Burdensome factors

\begin{tabular}{ll}
\hline Burdensome factors & $\begin{array}{l}\text { average } \\
\text { value }\end{array}$ \\
\hline Low motivation of students to engage in PE (unwillingness of students, pupils & 3.61 \\
nonpracticing) & 3.45 \\
Noise & 3.43 \\
Administrative activities & 3.26 \\
Increased risk of accidents during the PE & 3.10 \\
Number of pupils in lessons & 3.07 \\
Lack of sports equipment & 2.90 \\
Differences in ability of pupils it the class & 2.84 \\
Preparing and tidying up of tools & 2.72 \\
Other climatic conditions of sports fields (smell, cold, drafts, light) & 2.69 \\
Working with time (after-school activities - sports events, school trips, etc.) & \\
\hline
\end{tabular}

Research suggests that from a gender perspective teacher-women consider significant burden on lowstudents' motivation to exercise in physical education classes. Equally significant difference is also by the length of praxis of teachers. From this point of view, greater burden is seen by teachers with experience more than 20 years. 
Occupational health conditions

To the occupational health conditions we have included noise, which is one of the basic factors of physical deterioration of physical education teachers. It is caused by poor acoustics and poor sound insulation. High noise exposure leads to hearing disorders, headaches, migraines and other psychosomatic problems. König (2004) compares the noise at sport places with noise during breaks at school. Research suggests that the noise is one of the most burdensome factors for physical education teacher.

Spatial conditions of gyms and other sport places are not only problematic in terms of noise. According to Voltmann-Hummes (2008) contributes the number of students in the classroom, inadequate and obsolete equipment or poor climate to health impairments of teachers. Physical education teachers-women identified the lack of sports facilities as more burdensome compared to teachers-men. Probably due to a different approach to teaching physical education of men and women, where men prefer more ball games with a minimum of necessary tools and women prefer gymnastic elements that imply the use of more equipment.

Physical stress

Attention is also paid to physical stress, such as performing curriculum, preparing sport equipment or providing a help to pupils that may be particularly crucial for older teachers. However, in all surveyed areas there is slightly increased value by teachers under thirty years of their age. The reason may be eg. modern approach of younger teachers who use more of new tools or their own passion for physical activity.

Demonstration is a common educational practice used to clarify knowledge for students. It is most often used in conjunction with verbal explanations, and occasionally with tactile guidance. Demonstration can serve to explain or reinforce psychomotor skills, cognitive concepts and socio - affective behaviors. Physical educators seem to be particularly fond of using demonstrations. Perhaps this is because so many skills in physical education require specific movement patterns which can be communicated effectively through demonstration (Holst, 1997).

Physical education teachers should have a good physical condition also for preparing sport equipment especially for younger pupils. When physical education teachers perform new curriculum they have to have sufficient dexterity and physical strength to provide a help for preventing injuries of pupils.

\section{School team}

Another area that we focused on is the school team. Queries related to perceived burden from other teachers and the school management. Research suggests that teachers-women feel more strongly the lack of feedback from the school management. Conversely, below average are answers related to feeling of isolation from other teachers.

Many authors (eg. Hutchins \& Macdonald, 1993, Williams \& Williamson, 1998) describe the perceived lack burden of beginning teachers of physical education. They talk about the lack of support from colleagues and school management. It has to do with the overall marginality of the subject and the first entry into practice.

Most often teachers describe significant weaknesses in teamwork and the related lack of implementation of the tasks assigned by the school management. Much more consistency they feel in class among pupils (Schröder \& Schmitt, 1988, Friedman, 1991). 


\section{Psychological stress}

The research results confirm the emotional intensity of inactive students with physical education teachers. Wong \& Louie (2002) identified the lack of movement skills of students and their negative attitude to the subject of physical education as well as the area most stressful job as a teacher of physical education. For students, this course is not so important and it is more difficult for teachers to motivate students to actively participate in the lesson. No practicing students give little attention and distract them in class. It is difficult for them to distinguish indifference and laziness from the real health problems (Woods, 2008). The teacher has another group of people who have to enter some work.

The research results confirm that teachers over sixty years, it is difficult to cope with the lack of motivation of students. This can be interpreted to mean that older teachers are often struggling to cope with declining pupil motivation in general (Lazarová, 2011). Macdonald $(1995,1999)$ also confirms frustration by teachers caused by lack motivation and cooperation of students.

The mental health problems can include an increased risk of injury in physical education classes. Accidents at the school include a larger proportion of all injuries in sport (Kemeny, 1988). According to Rohnstock (2000) are from a health point of view more accidents than to overtraining, which contributes to maintaining frequent injuries of students in physical education classes. This increases demands on the teacher's attention. As previously mentioned, teachers this kind of mental stress considered to be relatively burdensome.

\section{DISCUSSION}

In comparison with the results Voltmann-Hummes (to take into account only the results of relating to primary schools - Hauptschule) it should be noted that Czech teachers seem to perceive the risk of pupils as significantly burdening factor in contrast to German research. According to research VoltmannHummes, German teachers see as significantly stressful factors such as noise, poor acoustics, the number of students, etc. This poses the question as relating to differences in equipment of workplaces, organization, training, the number of pupils in Czech and German environment.

It should be noted that the most stressful factor is the perceived lack of motivation of students for teaching in general. It seems that the load of the PE teachers has been complicated by increasingly mediamentioned reluctance of children to movement and sports in recent years.

Related to the low motivation of pupils we can talk about serious disciplinary problems that often occur during physical education lessons than in traditional ones. According to some authors (Barth, 1995, Wurzel, 1995, Scherler, 2000), this is due to the lighting in the games or team work during gymnastic activities. Some students are striving to emulate their role models and then it is difficult to manage impulsivity of students.

It also seems that an important burden factor of physical education teachers is noise, which is confirmed by Czech and German research. Research Voltmann-Hummes (2008) puts this aspect even in first place for teachers of all types of surveyed schools.

To the occupational health conditions we have included the problem of outdated or damaged equipment. A study conducted in Switzerland in 2005 tells to public problem with such sports equipment that may pose a risk of injury. Withal are these devices obsolete and in many cases do not correspond to current trends in 
teaching physical education. Financing of repairs or acquiring new equipment, however, is rarely the subject of allocation of funds to schools (Voltmann-Hummes, 2008).

If we talk about hygienic conditions, Escher stated, that a greater burden perceive younger teachers. However this fact has not been proven by our research (Voltmann - Hummes, 2008).

Although it may seem that regular physical activity has a positive effect against stress symptoms and reactions it can cause at the same time with increasing age, and in excess, serious health problems (Heim \& Gerlach, 1998). There is required that physical education teachers should have a certain level of physical fitness throughout their career, which they need to educate pupils, providing a help and moving with the space-consuming tools (Decker, 1998, König, 2004). The specific part of physical education teacher activity is active participation in skiing and other courses. Especially for older teachers, it means to keep fit and manage these sports with a high degree of intensity (Scherer \& Schüssler, 1983). Garske \& Holtz (1985) confirm the high demands on the physical stress of physical education teachers, which are much higher than in other subjects.

Research conducted in Sweden shows that teachers are leaving the profession around 40 years of age. Usually it is caused by the health problems that have incurred during professional career of physical education teacher. Only a fifth of teachers are still working in the field also in the age of 60 (Sandmark, 2000).

Noteworthy, it is also the burden applied to the obligation to pursue the administrative actions, but this is a factor that teachers generally perceived as very burdensome.

\section{CONCLUSIONS}

Monitoring of load in the teaching profession in recent years has become the centre of attention of number of studies in the Czech Republic and abroad (Řehulka, 2005, Paulík, 2011). Questions are about the burden of physical education teachers, who can be expected by specific load factors. Partial results of our research in the Czech environment suggest some similarity with German research, which has become the basis of our research. Our next research steps will aim to further understanding of the specifics of teaching physical education in general, using qualitative methods - interviews with physical education teachers.

We believe that qualitative probes will help us to probe deeper insight into the profession of teaching physical education and to identify the sources of occupational stress.

\section{REFERENCES}

1. Barth, A.R. (1995). Was betrifft mich das burn-out-Syndrom? Sportunterricht, 44, pp.141-151.

2. Bizet, I. et al. (2010). Career Changes Among Physical Educators: Searching for New Goals or ESCAPING A HEAVY TASK LOAD? Research Quarterly for Exercise and Sport, 81(2), pp.224232.

3. Blahutková, M., et al. (2005). Pohyb a duševní zdraví. Brno: Paido.

4. Decker, S. (1998). Zur allgemeinen Handlungsfähigkeit und Lehrkompetenz. Körpererziehung, 1, pp.21-27.

5. Friedman, I. A. (1991). High- and low-burnout schools: School culture aspects of teacher burnout. Journal of Educational Research, 84(6), pp.325-333. 
6. Garske, U. \& Holtz, U. (1985). Zur Arbeitsbelastung und den Arbeitsbedingungen von Sportlehrern. Sportunterricht, 34(9), pp.329-340.

7. Green, K. (1998). Philosophies, ideologies and the practice of physical education. Sport, Education and Society, 3(2), pp.125-143.

8. Heim, R. \& Gerlach, E. (1998). Burnout - Auch ein Thema im Sportlehrerberuf? Körpererziehung, 10, pp.330-337.

9. Heim, R. \& Klimek, G. (1999). Arbeitsbelastungen im Sportlehrerberuf- Entwicklung eines Instruments zur Erfassung fachunterrichtlicher Strssoren. Psychologie und Sport, 6(2), pp.35-45.

10. Hutchins, C.H. \& Macdonald, D. (1993). Beginning physical education teachers and early career decision-making. Physical Education Review, 16(2), pp.151-161.

11. Kemeny, P. (1988). Die Entwicklung der Unfallhäufigkeitten im Schlusport. Sportpädagogik, 12(5), pp.6-9.

12. König, S. (2004). Belastungen für Lehrkräfte im Sportunterricht. Sportwissenshaft, 34(2), pp.152165.

13. Lazarová, B. et al. (2011). Pozdní sběr. O práci zkušených učitelů. Brno: Paido.

14. Rohnstock, D. (2000). Belastungsschwerpunkte im Sportlehreralltag und Anregungen für gezielte Enlastungen. Sportunterricht, 49(4), 108 - 115.

15. Sandmark, H. (2000). Muscosceletal dysfunction in physical education teachers. Occupational and Environmental Medicine, 57, pp.673-677.

16. Scherer, H.G. \& Schüssler, P. (1983). Schilehrer können nicht nicht vormachten. Sportpädagogik, $7(2)$, pp.28-32.

17. Scherler, K.H. (2000). Machtkämpfe. Sportpädagogik, 24(6), pp.13-15.

18. Schröder, A. \& Schmitt, B. (1988). Soziale Unterstützung. In L. Brüderl (Hrsg.), Theorien und Methoden der Bewältigungsforschung (149-159). Weinheim: Juventa.

19. Van Holst, A. (1997). The use of demonstration in teaching physical education. Journal CAHPERD, 63(2), pp.20-22.

20. Voltmann-Hummes, I. (2008). Traumjob Sportlehrer/in? Belastungserleben und Selbstwirksamkeitserwartung von Schulsportlehrkräften. Göttingen: Cuvillier Verlag Göttingen.

21. Williams, J.A. \& Williamson, K.M. (1998). The socialization strategies of first-year physical education teachers; Conflict and concessions. Physical Educator, 55(2), pp.78-89.

22. Wong, A. \& Louie, L. (2002). What professional educators can learn from practicing physical education teachers? Physical Educator, 59(2), pp.90-104.

23. Woods, M. et al. (2008) Physical educators' technology competencies and usage. Physical Educator, 65(2), pp.82-99.

24. Wurzel, B. (1995). Die sozialen Beziehungen in der Schule als Wirkungskräfte im Prozess des Ausbrennens. Sportunterricht, 44(4), pp.152-162. 